\title{
同性婚姻合法化的社會影響
}

\section{The Social Impacts of}

\section{Legalizing Same-sex Marriage}

\author{
蔡祥元
}

Cai Xiangyuan

\section{Abstract}

From the perspective of the difference between Chinese and Western philosophy, Professor Zhang Xianglong demonstrates that Confucianism's attitude towards same-sex marriage is different from that of liberalism and the Christian tradition. The analysis in this article is deep and inspiring. However, in terms of the social problems that may be caused by the legalization of same-sex marriage, I think the author's arguments need to be further discussed. In fact, the legalization of same-sex marriage would not have as serious an effect on the marriage system, familial feelings and social ethos as he has supposed.

張祥龍教授通過對比西方自由主義、基督教文明, 表明儒家 對待同性婚姻合法化的基本立場。此文從思想義理、歷史事實、 當代社會形態等多個層面考察同性婚姻現象, 展示了此問題的複 雜性與深刻性。在深入剖析同性婚姻現象之後, 作者中肯而全面 地闡發了儒家對待同性婚姻的可能態度。它一方面能寬容地對待

蔡祥元, 山東大學儒學高等研究院副教授, 中國濟南, 郵編 : 250100。

Cai Xiangyuan, Associate Professor, Advanced Institute of Confucian Studies, Shandong University, Jinan, China, 250100.

《中外醫學哲學》XVI:2 (2018 年) : 頁 89-92。

International Journal of Chinese \& Comparative Philosophy of Medicine XVI:2 (2018), pp. 89-92.

(C) Copyright 2018 by Global Scholarly Publications. 
同性戀現象，把它視作反常的 “自然” 現象之一，聽任其存在， 不像基督教那樣完全排斥它; 另一方面, 從法律層面又不贊同自 由主義原則, 不認可同性戀婚姻合法化。此文的新意不在於這一 看似中庸的態度, 而是對這一 “中間” 態度的充滿張力的剖析, 裡面既緊扣現實, 又充滿哲理意趣。筆者在這裡完全贊同張祥龍 教授就同性戀現象展示出來的中西哲理差異的分析。但是, 在具 體對待同性婚姻可能造成的社會問題方面，筆者以為張祥龍教授 的相關論證還有進一步討論的餘地。

張從社會現實回應儒家如何不同意同性婚姻合法化的理由如 下：其一，同性戀合法化對婚姻制度造成破壞。他援引反對同性 戀婚姻合法化的法官羅伯茲的觀點表明, 如果同性婚姻合法, 會 進一步導致一夫多妻、一妻多夫以及多夫多妻的合法化, 從而導 致婚姻制度本身遭到破壞。其次, 同性戀合法化會傷害他人, 比 如, 杜絕了父母延續自己血脈的希望, 影響被收養孩子的性格乃 至性取向。第三, 同性婚姻合法化有可能誘使更多的人走向同性 戀的道路, 從而帶來更多家庭帶問題。但是, 這三個現實擔憂都 不是必要的。

先看第一個理由。現代婚姻法大都以一夫一妻為基本原則, 這並不只是受基督教文明的影響, 在我看來, 更是因為它符合性 資源配置的公正性原則。天然狀態下男女比例基本上是一比一對 等的。如果嬰兒的性別比例並不自然對等, 比如是一男二女, 或 者一女二男, 那麼, 在這種情況下, 公正的婚姻法應該是一夫二 妻或一妻二夫, 這樣才能原則上保證男女都有與異性結合的機 會。現代婚姻法的一夫一妻制正是暗中以此 “自然正義” 為原則 的。但是這一原則潛在地也會導致同性婚姻的合法化。因為在自 然狀態下, 天然存在一些性取向異常的人, 由於他們也是自然產 生的, 法律也應當保證他們的結婚權利。而從一夫一妻到同性婚 姻的跨度, 從社會正義的角度看, 也並不比從一夫一妻到一夫多 
妻（或一妻多夫）大，因為一夫多妻或一妻多夫會造成社會性資 源的分配不公，但同性婚姻卻不會有此影響。

理由二也同樣難以成立。張教授的顧慮是, 一旦結婚了, 就 斷了父母親可能具有後代的念頭。但這一顧慮沒有考慮到下列事 實：結婚與否, 並不改變人的性取向。當然我們可以設想, 同性 性取向者, 為了擁有子女, 跟某個異性結婚。這是禁止同性戀婚 姻的潛在好處。這種做法對父母來説自然是最好的結果, 滿足了 他們擁有自己正宗後代的願望。但是, 作為那個有夫妻之名但卻 無夫妻之實的另一半呢? 有誰願意自己的女兒或兒子跟一個同性 性取向的人結婚, 只為了滿足對方養育後代的需要呢? 他們的 “傷害”由誰來補償呢?

如果子女已經是同性戀, 同性婚姻合法與否, 並不能改變這 個事實, 那麼, 其父母在擁有後代方面的願望就無法以正常的方 式達成，這跟子女雙方中有一方或雙方都不孕的情況是一樣的。 對於這種既成事實, 在我看來, 父母多半只能認命。雖然如此, 父母還是希望子女擁有更體面的生活。同性婚姻合法化倒未嘗不 是一個選項。在合法化之前, 同性戀只能隱藏在地下, 由於沒有 法律的保障和約束, 同性戀的戀人關係往往很難穩固。愛滋病患 者在同性戀中的傳播比例遠遠高於異性戀, 跟同性戀沒有婚姻 “束縛” 有一定關係。因此, 就同性戀的父母而言, 如果子女作 為同性戀是無可改變的事實, 而同性婚姻可以讓子女擁有固定的 “家庭生活”，這倒也不失為“退而求其次”的選項。如果同性 雙方有意撫育子女, 領養一個孩子, 還能間接滿足父母及他們自 己擁有 “後代” 的願望。

當然, 這就有了另一個問題, 被領養的孩子在同性婚姻家庭 長大到底有多大影響。要説沒有影響, 那是不可能的。任何一個 孩子能夠被正常的異性戀家庭領養, 自然是更佳的選擇。但是我 們需要考慮, 被領養的孩子多半因為各種原因而被親生父母拋棄 的, 也不是所有被拋棄的孩子能夠被領養, 所以還是有不少數量 
的孩子只能在孤兒院長大。與孤兒院相比, 在同性婚姻家庭長大, 對孩子來説恐怕也是一個不錯的選擇，畢竟在這裡他們可以得到 更多關注與照顧。張教授一個最大的顧慮是, 被同性戀父母養大 的孩子, 其性取向可能被改變。但是, 他也援引有關人士的調查 表明性取向跟家庭環境（是異性戀還是同性戀家庭）沒有明顯關 係。雖然此種調查可能有局限性, 但沒有進一步調查表明性取向 會受撫養者性取向的影響, 不妨姑且接受這一點。

其三，擔心同性婚姻合法化會誘使產生更多同性戀，在我看 來也是沒有必要的。同性戀主要有兩類, 一類是先天的, 一類是 後天的。雙性戀介於前兩者之間, 就影響而言, 最關鍵的是針對 後天養成的同性戀。但是, 哪怕是後天影響導致的性取向轉變, 跟同性婚姻合法化與否, 也不一定有直接關聯。我們知道, 隱蔽 的東西往往更有神秘性, 具有更大的吸引力。相比于偷偷摸摸的 同性戀行為, 同性婚姻合法倒有可能揭掉同性戀的神秘面紗, 減 少其吸引力, 也未可知。

這麼説, 是否意味著儒家就該雙手贊成同性戀婚姻的合法化 呢? 既然儒家的哲理本身包含 “變” 的因素, 這種變的因素除了 態度上的寬容以外, 允許婚姻制度的某種變革當然是可能的。但 是, 我個人以為, 同性婚姻合法化與否, 或許並不是關鍵問題。 只要能夠秉承儒家的 “忠恕” 原則, 具有包容、理解的心態, 不 同性取向的人能夠相互尊重, 和諧共處, 合法與否都是可以接受 的。

\section{參考文獻 References}

張祥龍：〈儒家會如何看待同性婚姻的合法化? 〉, 《中外醫學哲學》, 2018 年, 第 XVI卷, 第 2 期, 頁 53-72。ZHANG Xianglong. “How Should Confucianism View the Legalization of Same-sex Marriage?” International Journal of Chinese \& Comparative Philosophy of Medicine XVI:2 (2018), pp.53-72. 